\title{
Quantification of the inevitable: the influence of soil macrofauna on soil water movement in rehabilitated open-cut mined lands
}

\author{
S. Arnold ${ }^{1}$ and E. R. Williams ${ }^{2,3}$ \\ ${ }^{1}$ Centre for Water in the Minerals Industry, Sustainable Minerals Institute, The University of Queensland, \\ St. Lucia, 4072, QLD, Australia \\ ${ }^{2}$ Centre for Mined Land Rehabilitation, Sustainable Minerals Institute, The University of Queensland, \\ St. Lucia, 4072, QLD, Australia \\ ${ }^{3}$ Agri-Science Queensland, Department of Agriculture and Fisheries, Kingaroy 4610, QLD, Australia \\ Correspondence to: S. Arnold (s.arnold@uq.edu.au)
}

Received: 23 July 2015 - Published in SOIL Discuss.: 14 August 2015

Revised: 8 December 2015 - Accepted: 3 January 2016 - Published: 21 January 2016

\begin{abstract}
Recolonisation of soil by macrofauna (especially ants, termites and earthworms) in rehabilitated open-cut mine sites is inevitable and, in terms of habitat restoration and function, typically of great value. In these highly disturbed landscapes, soil invertebrates play a major role in soil development (macropore configuration, nutrient cycling, bioturbation, etc.) and can influence hydrological processes such as infiltration, seepage, runoff generation and soil erosion. Understanding and quantifying these ecosystem processes is important in rehabilitation design, establishment and subsequent management to ensure progress to the desired end goal, especially in waste cover systems designed to prevent water reaching and transporting underlying hazardous waste materials. However, the soil macrofauna is typically overlooked during hydrological modelling, possibly due to uncertainties on the extent of their influence, which can lead to failure of waste cover systems or rehabilitation activities. We propose that scientific experiments under controlled conditions and field trials on post-mining lands are required to quantify (i) macrofauna-soil structure interactions, (ii) functional dynamics of macrofauna taxa, and (iii) their effects on macrofauna and soil development over time. Such knowledge would provide crucial information for soil water models, which would increase confidence in mine waste cover design recommendations and eventually lead to higher likelihood of rehabilitation success of open-cut mining land.
\end{abstract}

\section{Introduction}

In land restoration, practitioners are principally concerned with the residual physical properties of reconstructed landscape components and their assembly to either resemble the original configurations or develop novel designs that achieve acceptable functional outcomes (sensu lato ecological engineering by Mitsch and Jorgensen, 1989). Typically, the impact of macrofauna (e.g. ants, termites, earthworms) on soil structure is scarcely recognised by these ecological engineers and soil scientists, despite recognition by soil ecologists and entomologists that the soil macrofauna significantly contributes to ecosystem services such as soil forma- tion, water availability for vegetation, or flood and erosion control (Lavelle et al., 2006; Cerdà et al., 2009; Cerda and Jurgensen 2011), and soil development and fertility (Oo et al., 2013; Bottinelli et al., 2015). This omission of macrofauna from landscape design may in part be due to the current lack of quantitative knowledge of their role in the nature and timing of significant alterations to soil physical properties (e.g. the formation of macropores and soil aggregates) at the landscape scale, and their temporal evolution (Bottinelli et al., 2015). Such information is crucial for soil restoration and ongoing ecosystem productivity in degraded lands (Blouin et al., 2013; Jouquet et al., 2014; Frouz and Kuraz, 2013), where biodiversity and material-energy cycles are in- 


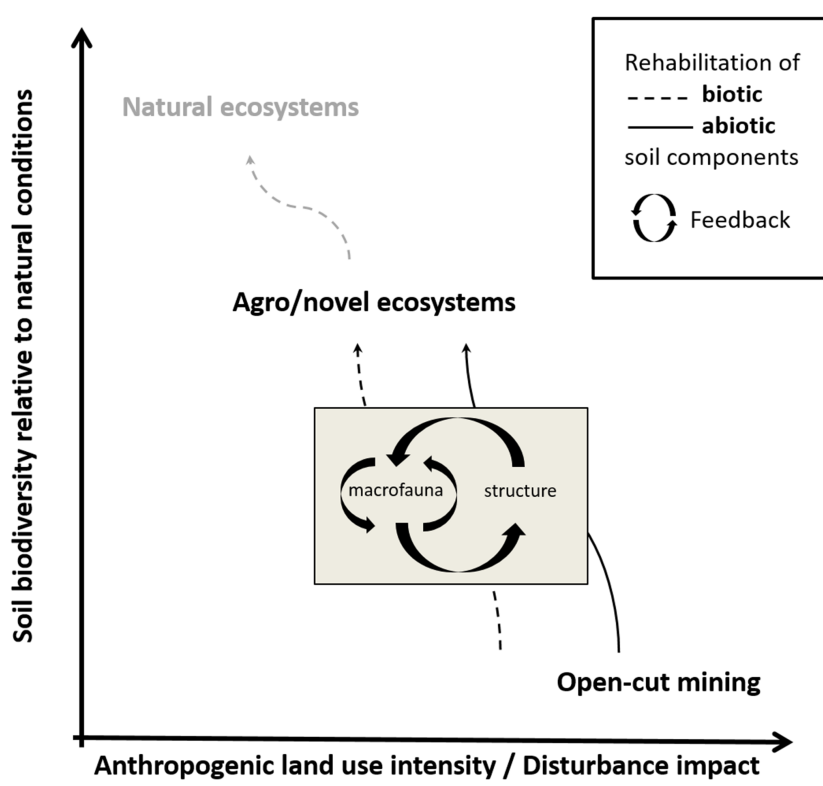

Figure 1. Relation between land use intensity/disturbance impact and soil biodiversity of natural ecosystems, conventional agriculture, and open-cut mining lands (modified after Bottinelli et al., 2015; Doley and Audet, 2013). While the transition from conventional agriculture to natural ecosystems mainly requires restoration of biotic soil components, the transition of open-cut mining land to novel (Perring et al., 2014), agricultural or native ecosystems (if possible) requires rehabilitation of both biotic and abiotic soil components. Feedbacks between different macrofauna taxa, as well as between macrofauna and soil structure, might be critical drivers of the temporal transition of open-cut mining land to novel or agricultural ecosystems.

terrupted and mainly driven by disturbances and land management history (e.g. for agriculture, the history of tillage and pesticide application; Bottinelli et al., 2015; Doley and Audet, 2013). The perturbation of normal soil-forming processes is exacerbated in open-cut mining lands, where topographical and geological ecosystem elements are disrupted at the landscape-scale (Fig. 1). In this regard, and throughout this article, we refer to "ecosystem rehabilitation" as the process of attempting to reinstate ecosystem functions and services (Seastedt et al., 2008; Audet et al., 2013; Doley and Audet, 2013; Aronson et al., 1993) as opposed to "ecosystem restoration", which aims to reinstate the structure, functioning, and dynamics of historical (pristine) ecosystems (Aronson et al., 1993; Hobbs et al., 2006).

Numerical models of environmental processes are a critical component of any planning scheme for the management of human-impacted ecosystems (Arnold et al., 2014, 2012b) or for the design and construction of facilities aiming to protect ecosystems and local communities from hazardous materials such as mine waste (Arnold et al., 2015; Gwenzi et al., 2013; O'Kane and Wels, 2003). For example, modelling of soil water dynamics is essential at the early design stage of mine waste rock storage facilities. However, if model assumptions about material properties are based on their initial state rather than after their temporal evolution, such facilities may fail to attain their long-term design objectives (Taylor et al., 2003). On the other hand, a sensible balance between the complexity and uncertainty of numerical models is required to use them as exploratory or management tools (Arnold et al., 2012a). We acknowledge the effects of plant roots on soil hydraulic properties and preferential flow, as well as the progress in numerical modelling of root system architecture and root water uptake in recent years (Bargués Tobella et al., 2014; Carminati et al., 2011; Javaux et al., 2008; Schröder et al., 2008). However, we believe that macrofauna-soil structure interactions rather than root-soil interactions play a critical role in the soil water distribution at the early stage of soil reconstruction, particularly if plant available water is the predominant abiotic stressor (Arnold et al., 2013).

While the recent review article of Bottinelli et al. (2015) advocates collaboration between soil ecologists and physicists in order to increase understanding of soil-plant water relations, their review is limited to natural and agricultural ecosystems subjected to low or moderate levels of disturbance. As an extension of their work, we propose that interactions between soil fauna and soil structure dynamics are even more critical for severely disturbed ecosystems such as in open-cut mining lands. Therefore, in this short communication article, we (i) consider the impact of macrofauna on the rehabilitation of open-cut mine lands, specifically the effects of ants/termites and mine waste facilities, and (ii) indicate how further research on feedbacks between macrofauna and soil structure may help to reduce uncertainties in the prediction of soil water movement in rehabilitated mine environments, especially toxic waste covers.

\section{Socio-ecological impacts of open-cut mining}

Both biotic (e.g. fauna, vegetation, microbes) and abiotic (e.g. water, soil material, meteorological variables) ecosystem components are fundamental drivers of material and energy cycles, and thereby govern ecosystem structure and function. During open-cut mining, many ecosystem components, including these material and energy cycles, undergo significant physical and chemical disturbances and may be irreversibly disrupted to at least some extent (Fig. 1).

After mining activities are complete, the topography and physical soil properties are reconstructed in an attempt to establish the foundation of a self-sustaining ecosystem. However, soil properties are still markedly different compared to unmined areas, including higher bulk density (Potter et al., 1988), lower soil water content and lower soil water potential (Ngugi et al., 2015). As soil development is integral in various ecosystem functions (e.g. carbon, nutrient and water cycles, and vegetation establishment; Pallavini et al., 2015; Smith et al., 2015), these alterations have long-lasting effects 
on successful ecosystem rehabilitation. At this initial stage and at the landscape scale, soil biodiversity is reduced and/or disrupted to an extent that could almost be referred to as "sterile" (Rives et al., 1980; Miller et al., 2011). In addition to this initial sterile conditions, open-cut mining often results in the generation of hazardous wastes in the form of either coarse-grained waste rock that is separated before mineral processing or fine-grained processing wastes (tailings) (Lottermoser, 2010). These waste materials are then deposited at the mine site and require rehabilitation. One form of rehabilitation that is increasingly accepted for closure of mining waste facilities is the use of vegetated mine waste cover systems (Arnold et al., 2014b; Gwenzi et al., 2013). These evapotranspiration cover systems are also referred to as monolithic alternative covers (Albright et al., 2004), phytocaps (Venkatraman and Ashwath, 2010), or store and release covers (Fourie and Tibbett, 2007; Wilson et al., 2003). Their design aims to minimise drainage into underlying hazardous wastes. Contrary to conventional covers made of compacted clay, geosynthetic clay liners, or polyvinyl chloride (Othman et al., 1994; Benson, 2000; Levin and Hammod, 1990), phytocaps serve two purposes: (1) to maximise rainfall interception by vegetation and, if required, a compacted soil layer, and (2) to remove soil water through plant transpiration and evaporation from bare soil (Salt et al., 2011). Through successive rainfall events, the loss of stored soil water through evapotranspiration decreases net percolation through the soil (Hauser et al., 2001; Rock, 2010) and reduces surface runoff and erosion.

Regardless of the rehabilitation design, the soil macrofauna is particularly important in this initial stage of rehabilitation (Frouz and Kuraz, 2013), due to their rapid recolonisation, particularly by generalist taxa that have long-distance dispersal strategies. For example, the typical dispersal strategy for many ant species is by nuptial flights (Peeters and Molet, 2009), where copulation occurs in the air after specific climatic cues and queens fly from $100 \mathrm{~m}$ to $10 \mathrm{~km}$ from their originating nest to find suitable habitat before dropping their wings and establishing a new nest (Hölldobler and Wilson, 1990). Initially, a limited number of individuals are produced from newly laid eggs and colony survival depends on food resources, which for ants (omnivores) include seeds (e.g. from topsoil spreading or revegetation activities), other fauna (invertebrates or vertebrates and their products) or other organic matter (Blüthgen and Feldhaar, 2009). As these newly established colonies are small, not much food is required for survival until further resources become available. Thus, colony foundation at rehabilitated mine sites can occur within weeks (Williams, personal observation) and prior to vegetation establishment from seeds.

However, deterioration in cover performance and even failure can be caused by increased soil permeability resulting from (i) the formation of shrinkage cracks and (ii) macropores associated with root channels or (iii) ant and termite galleries (Taylor et al., 2003) or (iv) burrowing macrofauna such as earthworms (Edwards et al., 1990; Frouz and Kuraz, 2013). While the importance of the first two causes has been accepted by soil scientists (e.g. Bengough et al., 2011, 2006; Czarnes et al., 2000; Hinsinger et al., 2009; Ranatunga et al., 2008), the contribution of soil macrofauna to waste cover failure has been largely overlooked (Taylor et al., 2003). For example, in their report about the deterioration in performance of a waste rock cover facility in tropical Australia, Taylor et al. (2003) concluded that, amongst (i) and (ii), the formation of termite galleries played a critical role.

\section{The price to pay for negligence}

At post-mining sites, the type of mineral processing initially determines the soil properties, as well as the depth of overburden and topsoil materials removed from mine pits (Gould, 2012; Erskine and Fletcher, 2013). Likewise, the method and equipment used to reconstruct topsoil affects soil hydraulic properties (Fourie and Tibbett, 2007). However, within weeks after topsoil establishment, the first colonisers such as soil-nesting ants (e.g. Iridomyrmex species in Australia) build underground galleries, thereby initiating changes in soil properties (Lee and Foster, 1991). This macrofauna alters the local soil structure and profile characteristics (Jones et al., 1994; De Bruyn and Conacher, 1994); influence soil aggregate stability (Cammeraat and Risch, 2008; Lavelle et al., 2006), water infiltration and mechanical strength (Eldridge, 1994; Frouz and Kuraz, 2013); and increase the field capacity through the formation of holo-organic and organomineral aggregates (Frouz and Kuraz, 2013). That is, soil macrofauna introduces or increases heterogeneity of soil properties. Mound-building ants, for example, excavate soil material and thereby increase the number of macropores, which leads to a lower bulk density (Dostál et al., 2005; Cammeraat and Risch, 2008; Jones et al., 1994). These changes in soil features lead to increasing infiltration rates under wet conditions (Cammeraat et al., 2002). Some ant species bring soil material from deep soil horizons to the surface (Folgarait, 1998) or damage geotextiles, which can have negative impacts on the functionality of compacted barrier layers through the creation of preferential flow paths (Manassero et al., 2013; O'Kane Consultants Inc., 2003). Later during ecosystem rehabilitation, burrowing macrofauna such as earthworms affect the soil structure and profile characteristics in a similar manner by modifying the pore and aggregate size distribution, the soil bulk density, and soil organic matter, eventually affecting the soil water-holding capacity and infiltration rates (Blouin et al., 2013; Jouquet et al., 2014; Frouz and Kuraz, 2013). The qualitative and quantitative impact of macrofauna on hydrological variables (e.g. infiltration) depends on the taxa and species involved, the soil type, the successional stage of the ecosystem, and the initial soil water conditions (Cammeraat and Risch, 2008; Cammeraat et al., 2002). 
Table 1. Proposed approaches to collect empirical data in relation to ant-soil interactions.

\begin{tabular}{lll}
\hline & Glasshouse/laboratory & Post-mining land \\
\hline Methodology* $_{\text {Investigative scale* }}$ & Controlled/manipulative experiments & Field trials with control site \\
Knowledge gap & Quantity and conditions of colonisation rates & Medium \\
& Effects on soil hydraulics & Succession of colonisation \\
& & Long-term water availability for plants \\
\hline
\end{tabular}

* Arnold et al. (2013)

Additional uncertainties with respect to soil properties arise during ecosystem development. Specifically, unlike static engineered structures such as bridges, water levees, or dam walls, the reconstruction of soil for the purpose of ecosystem rehabilitation or waste cover systems must allow for structural and functional changes. The temporal evolution of soils on post-mining lands is affected by various biotic taxa during recolonisation and compositional changes over time, including vegetation and soil macrofauna such as ants and termites (Taylor et al., 2003).

Numerical models of the one-dimensional water movement through a vertical unsaturated soil column are typically based on the Richards equation (Richards, 1931), which requires knowledge of the effective soil hydraulic properties. A range of hydraulic models are suitable to describe unimodal soil water retention curves (Brooks and Corey, 1964; Kosugi, 1996; van Genuchten, 1980; Vogel et al., 1991); however, in open-cut mining lands where the formation of secondary pore systems is common (e.g. in waste rock materials), multimodal soil water retention curves are an appropriate means to describe soil moisture and hydraulic conductivity characteristics in relation to soil water pressure conditions (Durner, 1994). Hence, at the early stage of soil reconstruction, model uncertainty is relatively low (Fig. 2) because the models include well-quantified soil parameters, and in reality, macrofauna contributes minimally to the hydraulic soil properties. However, even at a low level of complexity, these models tend to lose their predictive power over time due to pedological processes that may be ignored in the initial soil water model but which later lead to significant material changes such as increasing saturated hydraulic conductivities (Fourie and Tibbett, 2007), particularly in layers of low permeability (Taylor et al., 2003). Even more critical is the lack of quantitative knowledge about the role of macrofauna processes for soil hydraulic properties at subsequent stages of soil reconstruction. Any empirical data, be it in the form of manipulative experiments under controlled conditions or in situ field trials, would make a significant contribution to integrate the temporal impact of macrofauna on soil development into numerical soil water models.

Although this integration increases model complexity and thereby model uncertainty, it can result in more predictive power and confidence if these interactions are well quantified

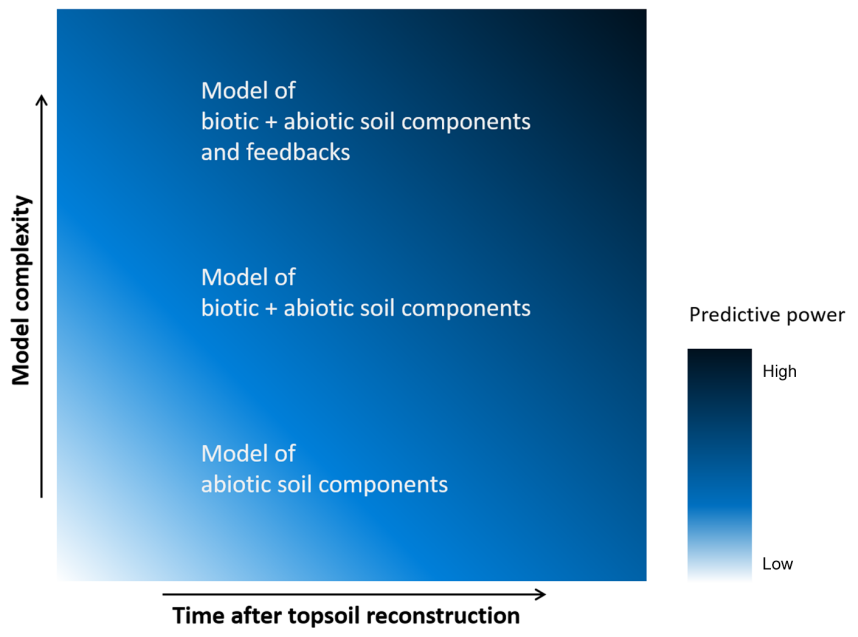

Figure 2. Conceptual scheme of predictive power of soil water models at different levels of complexity. While uncertainty in hydrological variables such as deep drainage or plant available water is lowest for traditional models that only consider abiotic soil components, these models may also have low predictive power due to omission of critical macrofauna-soil structure interactions. Integration of biotic components and feedbacks between macrofauna taxa, as well as between macrofauna and soil development, increases model complexity and thereby uncertainty. However, quantification of macrofauna-soil interactions by controlled scientific experiments reduces these uncertainties, thereby increasing the predictive power to a level acceptable to assess the risk of potential failure of postmining land rehabilitation.

(Arnold et al., 2012a). In this regard, more complex models provide the opportunity to include the temporal changes in soil material properties due to pedological and biological processes. For example, while some ant species increase infiltration rates (De Bruyn and Conacher, 1990; Eldridge, 1993; Cerdà and Jurgensen, 2008), other species may have a contrary impact on infiltration (Sarr et al., 2001; Navarro and Jaffe, 1985). Infiltration rates may vary between different locations or stages of ecosystem development, thereby affecting several aspects of the soil water balance and the availability of plant material for faunal consumption, and in turn the colonisation of the site by different ant species (Williams, 2011). Likewise, while feedbacks between the temporal evo- 
lution of macrofauna and soil structure increase model complexity and uncertainty, they could play a critical role in predicting the long-term performance and hence the design of waste cover facilities (Taylor et al., 2003) or post-mining lands (Frouz et al., 2006), which ultimately leads to a higher probability of rehabilitation success and the construction of self-sustaining post-mining landscapes.

\section{Conclusions and further directions}

Soil colonisation by macrofauna such as ants and termites on post-mining rehabilitation sites is inevitable. Due to the significant effects of these macrofauna on soil structure, we conclude that macrofauna needs to be considered by ecological engineers when designing and reconstructing lands after open-cut mining. In this regard, rehabilitation plans should include numerical soil water models that consider the temporal evolution of (i) macrofauna-soil structure interactions, and (ii) feedbacks between macrofauna taxa, as well as between macrofauna and soil development, over time.

We suggest two alternative approaches to collect empirical data (Table 1) that can be used to initially quantify these interactions and eventually to reduce uncertainty in modelled hydrological variables such as deep drainage, infiltration, or plant available water (Léonard et al., 2004). For example, manipulative experiments under controlled conditions are effective means to assess the impact of early colonisers on the soil water dynamics. A soil chamber or column (Joschko et al., 1989, 1992) can be used as a formicarium (Wang et al., 1995), where an ant nest is transplanted (including queen and workers) and food, water and nesting resources provided. Predefined water regimes could then be administered to simulate rainfall events, while the temporal dynamics of soil water potential and content are monitored across the soil profile. Similarly, these small-scale experiments are suitable for assessing the colonisation rates and environmental conditions (e.g. $\mathrm{pH}$, temperature, humidity, soil water content) required to colonise soils by ants. At a larger investigative scale (Table 1), field trials in combination with untreated control or reference sites are effective means to assess the impact of macrofauna on soil structure and inter-specific fauna interactions (feedbacks) in relation to soil biodiversity and soil development (Cammeraat et al., 2002). In this regard, opencut mining lands may provide ideal environments, because the physical properties of reconstructed soils are fundamentally different (and less complex) from those of degraded but physically intact soils.

Acknowledgements. The authors would like to thank David Doley for critical discussions and encouragement to publish this paper, as well as the three anonymous reviewers for constructive comments.

Edited by: E. Nadal Romero

\section{References}

Albright, W. H., Benson, C. H., Gee, G. W., Roesler, A. C., Abichou, T., Apiwantragoon, P., Lyles, B. F., and Rock, S. A.: Field water balance of landfill final covers, J. Environ. Qual., 33, 23172332, 2004.

Arnold, S., Lechner, A., and Baumgartl, T.: Merging modelling and experimental approaches to advance ecohydrological system understanding., in: Revisiting experimental catchment studies in forest hydrology, edited by: Webb, A. A., Bonell, M., Bren, L., Lane, P. N. J., McGuire, D., Neary, D. G., Nettles, J., Scott, D. F., Stednick, J. D., and Wang, Y., IAHS Publications, 117-124, 2012a.

Arnold, S., Thornton, C., and Baumgartl, T.: Ecohydrological feedback as a land restoration tool in the semi-arid Brigalow Belt, QLD, Australia, Agriculture, Ecosyst. Environ., 163, 61-71, doi:10.1016/j.agee.2012.05.020, 2012b.

Arnold, S., Audet, P., Doley, D., and Baumgartl, T.: Hydropedology and Ecohydrology of the Brigalow Belt, Australia: Opportunities for Ecosystem Rehabilitation in Semiarid Environments, gsvadzone, 12, doi:10.2136/vzj2013.03.0052, 2013.

Arnold, S., Attinger, S., Frank, K., Baxter, P., Possingham, H., and Hildebrandt, A.: Ecosystem management along ephemeral rivers: Trading off socio-economic water supply and vegetation conservation under flood regime uncertainty, River Res. Appl., doi:10.1002/rra.2853, 2014.

Arnold, S., Schneider, A., Doley, D., and Baumgartl, T.: The limited impact of vegetation on the water balance of mine waste cover systems in semi-arid Australia, Ecohydrology, 8, 355-367, doi:10.1002/eco.1485, 2015.

Aronson, J., Floret, C., Le Floc'h, E., Ovalle, C., and Pontanier, R.: Restoration and Rehabilitation of Degraded Ecosystems in Arid and Semi-Arid Lands. I. A View from the South, Restor. Ecol., 1, 8-17, doi:10.1111/j.1526-100X.1993.tb00004.x, 1993.

Audet, P., Gravina, A., Glenn, V., McKenna, P., Vickers, H., Gillespie, M., and Mulligan, D.: Structure of vegetation development on rehabilitated North Stradbroke Island: above/belowground feedback may facilitate alternative ecological outcomes, Ecol. Process, 2, p. 20, 2013.

Bargués Tobella, A., Reese, H., Almaw, A., Bayala, J., Malmer, A., Laudon, H., and Ilstedt, U.: The effect of trees on preferential flow and soil infiltrability in an agroforestry parkland in semiarid Burkina Faso, Water Resour. Res., 50, 3342-3354, doi:10.1002/2013wr015197, 2014.

Bengough, A. G., Bransby, M. F., Hans, J., McKenna, S. J., Roberts, T. J., and Valentine, T. A.: Root responses to soil physical conditions; growth dynamics from field to cell, J. Exp. Bot., 57, 437447, doi:10.1093/jxb/erj003, 2006.

Bengough, A. G., McKenzie, B. M., Hallett, P. D., and Valentine, T. A.: Root elongation, water stress, and mechanical impedance: a review of limiting stresses and beneficial root tip traits, J. Exp. Bot., 62, 59-68, doi:10.1093/jxb/erq350, 2011.

Benson, C. H.: Liners and covers for waste containment, 4th Kansai International Geotechnical Forum, Japan, 1-40, 2000.

Blouin, M., Hodson, M. E., Delgado, E. A., Baker, G., Brussaard, L., Butt, K. R., Dai, J., Dendooven, L., Peres, G., Tondoh, J. E., Cluzeau, D., and Brun, J. J.: A review of earthworm impact on soil function and ecosystem services, Eur. J. Soil Sci., 64, 161182, 2013. 
Blüthgen, N. and Feldhaar, H.: Food and shelter: How resources influence ant ecology, in: Ant ecology, edited by: Lach, L., Parr, C., and Abbott, K., Oxford University Press, Oxford, 2009.

Bottinelli, N., Jouquet, P., Capowiez, Y., Podwojewski, P., Grimaldi, M., and Peng, X.: Why is the influence of soil macrofauna on soil structure only considered by soil ecologists?, Soil Till. Res., 146, 118-124, doi:10.1016/j.still.2014.01.007, 2015.

Brooks, R. H. and Corey, A. T.: Hydraulic properties of porous media, Hydrol. Paper No. 3, Colorado State University, Fort Collins, CO, 1964

Cammeraat, E. L. H. and Risch, A. C.: The impact of ants on mineral soil properties and processes at different spatial scales, J. Appl. Entomol., 132, 285-294, doi:10.1111/j.14390418.2008.01281.x, 2008.

Cammeraat, E. L. H., Willott, S. J., Compton, S. G., and Incoll, L. D.: The effects of ants' nests on the physical, chemical and hydrological properties of a rangeland soil in semi-arid Spain, Geoderma, 105, 1-20, doi:10.1016/S0016-7061(01)00085-4, 2002.

Carminati, A., Schneider, C. L., Moradi, A. B., Zarebanadkouki, M., Vetterlein, D., Vogel, H.-J., Hildebrandt, A., Weller, U., Schüler, L., and Oswald, S. E.: How the Rhizosphere May Favor Water Availability to Roots, gsvadzone, 10, 988-998, doi:10.2136/vzj2010.0113, 2011.

Cerdà, A. and Jurgensen, M. F.: The influence of ants on soil and water losses from an orange orchard in eastern Spain, J. Appl. Entomol., 132, 306-314, doi:10.1111/j.14390418.2008.01267.x, 2008.

Cerdà, A., Jurgensen, M. F., and Bodi, M. B.: Effects of ants on water and soil losses from organically-managed citrus orchards in eastern Spain, Biologia, 3, 527-531, doi:10.2478/s11756-0090114-7, 2009.

Czarnes, S., Hallett, P. D., Bengough, A. G., and Young, I. M.: Rootand microbial-derived mucilages affect soil structure and water transport, Eur. J. Soil Sci., 51, 435-443, doi:10.1046/j.13652389.2000.00327.x, 2000.

De Bruyn, L. and Conacher, A.: The role of termites and ants in soil modification - a review, Soil Res., 28, 55-93, doi:10.1071/SR9900055, 1990.

De Bruyn, L. and Conacher, A.: The bioturbation activity of ants in agricultural and naturally vegetated habitats in semiarid environments, Soil Res., 32, 555-570, doi:10.1071/SR9940555, 1994.

Doley, D. and Audet, P.: Adopting novel ecosystems as suitable rehabilitation alternatives for former mine sites, Ecol. Process., 2, doi:10.1186/2192-1709-2-33, 2013.

Dostál, P., Březnová, M., Kozlíčková, V., Herben, T., and Kovár, P.: Ant-induced soil modification and its effect on plant below-ground biomass, Pedobiologia, 49, 127-137, doi:10.1016/j.pedobi.2004.09.004, 2005.

Durner, W.: Hydraulic conductivity estimation for soils with heterogeneous pore structure, Water Resour. Res., 30, 211-223, doi:10.1029/93wr02676, 1994.

Edwards, W. M., Shipitalo, M. J., Owens, L. B., and Norton, L. D.: Effect of Lumbricus terrestris L. burrows on hydrology of continuous no-till corn fields, Geoderma, 46, 73-84, doi:10.1016/00167061(90)90008-W, 1990.

Eldridge, D.: Effect of ants on sandy soils in semi-arid eastern Australia - Local distribution of nest entrances and their effect on infiltration of water, Soil Res., 31, 509-518, doi:10.1071/SR9930509, 1993.
Eldridge, D. J.: Nests of ants and termites influence infiltration in a semiarid woodland, Pedobiologia, 38, 481-492, 1994.

Erskine, P. and Fletcher, A.: Novel ecosystems created by coal mines in central Queensland's Bowen Basin, Ecol. Process., 2, 965-981, 2013.

Folgarait, P.: Ant biodiversity and its relationship to ecosystem functioning: a review, Biodivers. Conserv., 7, 1221-1244, doi:10.1023/a:1008891901953, 1998.

Fourie, A. and Tibbett, M.: Post-mining landforms - engineering a biological system, Mine Closure Santiago, Chile, 2007.

Frouz, J. and Kuraz, V.: Soil fauna and soil physical properties, in: Soil Biota and Ecosystem Development in Post Mining Sites, edited by: Frouz, J., CRC Press, Boca Raton, 265-278, 2013.

Frouz, J., Elhottová, D., Kuráž, V., and Šourková, M.: Effects of soil macrofauna on other soil biota and soil formation in reclaimed and unreclaimed post mining sites: Results of a field microcosm experiment, Appl. Soil Ecol., 33, 308-320, doi:10.1016/j.apsoil.2005.11.001, 2006.

Gould, S. F.: Comparison of Post-mining Rehabilitation with Reference Ecosystems in Monsoonal Eucalypt Woodlands, Northern Australia, Restoration Ecol., 20, 250-259, doi:10.1111/j.1526100X.2010.00757.x, 2012.

Gwenzi, W., Hinz, C., Bleby, T. M., and Veneklaas, E. J.: Transpiration and water relations of evergreen shrub species on an artificial landform for mine waste storage versus an adjacent natural site in semi-arid Western Australia, Ecohydrology, 7, 965-981, doi:10.1002/eco.1422, 2013.

Hauser, V., Weand, B., and Gill, M.: Natural Covers for Landfills and Buried Waste, J. Environ. Eng., 127, 768-775, doi:10.1061/(asce)0733-9372(2001)127:9(768), 2001.

Hinsinger, P., Bengough, A. G., Vetterlein, D., and Young, I.: Rhizosphere: biophysics, biogeochemistry and ecological relevance, Plant Soil, 321, 117-152, doi:10.1007/s11104-008-98859, 2009.

Hobbs, R. J., Arico, S., Aronson, J., Baron, J. S., Bridgewater, P., Cramer, V. A., Epstein, P. R., Ewel, J. J., Klink, C. A., Lugo, A. E., Norton, D., Ojima, D., Richardson, D. M., Sanderson, E. W., Valladares, F., Vilà, M., Zamora, R., and Zobel, M.: Novel ecosystems: theoretical and management aspects of the new ecological world order, Global Ecol. Biogeogr., 15, 1-7, doi:10.1111/j.1466-822X.2006.00212.x, 2006.

Hölldobler, B. and Wilson, E.: The Ants, Harvard University Press, Cambridge, 1990.

Javaux, M., Schröder, T., Vanderborght, J., and Vereecken, H.: Use of a Three-Dimensional Detailed Modeling Approach for Predicting Root Water Uptake, Vadose Zone J., 7, 1079-1088, doi:10.2136/vzj2007.0115, 2008.

Jones, C. G., Lawton, J. H., and Shachak, M.: Organisms as ecosystem engineers, Oikos, 69, 373-386, 1994.

Joschko, M., Diestel, H., and Larink, O.: Assessment of earthworm burrowing efficiency in compacted soil with a combination of morphological and soil physical measurements, Biol. Fert. Soils, 8, 191-196, doi:10.1007/BF00266478, 1989.

Joschko, M., Söchtig, W., and Larink, O.: Functional relationship between earthworm burrows and soil water movement in column experiments, Soil Biol. Biochem., 24, 1545-1547, doi:10.1016/0038-0717(92)90148-Q, 1992. 
Jouquet, P., Blanchart, E., and Capowiez, Y.: Utilization of earthworms and termites for the restoration of ecosystem functioning, Appl. Soil Ecol., 73, 34-40, 2014.

Kosugi, K. I.: Lognormal Distribution Model for Unsaturated Soil Hydraulic Properties, Water Resour. Res., 32, 2697-2703, doi:10.1029/96wr01776, 1996.

Lavelle, P., Decaëns, T., Aubert, M., Barot, S., Blouin, M., Bureau, F., Margerie, P., Mora, P., and Rossi, J. P.: Soil invertebrates and ecosystem services, Eur. J. Soil Biol., 42, S3-S15, doi:10.1016/j.ejsobi.2006.10.002, 2006.

Lee, K. and Foster, R.: Soil fauna and soil structure, Soil Res., 29, 745-775, doi:10.1071/SR9910745, 1991.

Léonard, J., Perrier, E., and Rajot, J. L.: Biological macropores effect on runoff and infiltration: a combined experimental and modelling approach, Agriculture, Ecosyst. Environ., 104, 277285, doi:10.1016/j.agee.2003.11.015, 2004.

Levin, S. and Hammod, M.: Application of PVC in a "Top Cap" application in: Geosynthetic Testing for Waste Containment Applications, edited by: Robert, M., American Society for Testing and Materials, Philadelphia, PA, 1990.

Lottermoser, B.: Mine Wastes: Characterization, Treatment and Environmental Impacts, 3rd Edn., Springer, Berlin Heidelberg, 400 pp., 2010.

Manassero, M., Dominijanni, A., Foti, S., and Musso, G.: Coupled phenomena in environmental geotechnics, CRC Press, 2013.

Miller, C., Franklin, J., and Buckley, D.: Effects of soil amendment treatments on American chestnut performance and physiology on an East Tennessee surface mine, National Meeting of the American Society of Mining and Reclamation, Bismarck, ND, 2011.

Mitsch, W. J. and Jorgensen, S. E.: Introduction to Ecological Engineering, in: Ecological Engineering: An Introduction to Ecotechnology, edited by: Mitsch, W. J. and Jorgensen, S. E., John Wiley \& Sons, New York, 3-12, 1989.

Navarro, J. G. and Jaffe, K.: On the Adaptive Value of Nest Features in the Grass-Cutting Ant Acromyrmex landolti, Biotropica, 17, 347-348, doi:10.2307/2388602, 1985.

Ngugi, M. R., Neldner, V. J., Doley, D., Kusy, B., Moore, D., and Richter, C.: Soil moisture dynamics and restoration of selfsustaining native vegetation ecosystem on an open-cut coal mine, Restor. Ecol., 23, 615-624, doi:10.1111/rec.12221, 2015.

O'Kane, M. and Wels, C.: Mine waste cover system design - linking predicted performance to groundwater and surface water impacts, 6th International Conference on Acid Rock Drainage (ICARD), Cairns, 2003.

O'Kane Consultants Inc.: Evaluation of the long-term performance of dry cover systems - Phase 2 Final Report, 2003.

Oo, A. N., Iwai, C. B., and Saenjan, P.: Soil properties and maize growth in saline and nonsaline soils using cassava-industrial waste compost and vermicompost with or without earthworms, Land Degrad. Dev., 26, 300-310, doi:10.1002/ldr.2208, 2013.

Othman, M., Benson, C., Chamberlain, E., and Zimmie, T.: Laboratory testing to evaluate changes in hydraulic conductivity caused by freeze thaw: state of the art, in: Hydraulic Conductivity and Waste Containment Transport in Soils, edited by: Trautwein, S. and Daniel, D., 227-254, 1994.

Pallavicini, Y., Alday, J. G., and Martínez-Ruiz, C.: Factors affecting herbaceous richness and biomass accumulation patterns of reclaimed coal mines, Land Degrad. Dev., 26, 211-217, doi:10.1002/ldr.2198, 2015.
Peeters, C. and Molet, M.: Colonial reproduction and life histories, in: Ant ecology, edited by: Lach, L., Parr, C., and Abbott, K., Oxford University Press, Oxford, 2009.

Perring, M., Audet, P., and Lamb, D.: Novel ecosystems in ecological restoration and rehabilitation: Innovative planning or lowering the bar?, Ecol. Process., 3, doi:10.1186/2192-1709-3-8, 2014.

Potter, K. N., Carter, F. S., and Doll, E. C.: Physical properties of constructed and undisturbed soils, Soil Sci. Soc. Am. J., 52, 1435-1438, 1988.

Ranatunga, K., Nation, E. R., and Barratt, D. G.: Review of soil water models and their applications in Australia, Environ. Model. Softw., 23, 1182-1206, doi:10.1016/j.envsoft.2008.02.003, 2008.

Richards, L. A.: Capillary conduction of liquids through porous mediums, J. Appl. Phys., 1, 318-333, doi:10.1063/1.1745010, 1931.

Rives, C., Bajwa, M., Liberta, A., and Miller, R.: Effect of topsoil storage during surface mining on the viability of VA Mycorrhiza, Soil Sci., 129, 253-257, 1980.

Rock, S.: Evapotranspiration covers for landfills, in: Application of Phytotechnologies for Cleanup of Industrial, Agricultural, and Wastewater Contamination, edited by: Kulakow, P., and Pidlisnyuk, V., Springer, Dordrecht, 189-198, 2010.

Salt, M., Lightbody, P., Stuart, R., Albright, W., and Yeates, R.: Guidelines for the assessment, design, construction and maintenance of phytocaps as final covers for landfills, United States Environmental Protection Agency report number, REF No. 20100260RA3F, 2011.

Sarr, M., Agbogba, C., Russell-Smith, A., and Masse, D.: Effects of soil faunal activity and woody shrubs on water infiltration rates in a semi-arid fallow of Senegal, Appl. Soil Ecol., 16, 283-290, doi:10.1016/S0929-1393(00)00126-8, 2001.

Schröder, T., Javaux, M., Vanderborght, J., Körfgen, B., and Vereecken, H.: Effect of Local Soil Hydraulic Conductivity Drop Using a Three-Dimensional Root Water Uptake Model, Vadose Zone J., 7, 1089-1098, doi:10.2136/vzj2007.0114, 2008.

Seastedt, T. R., Hobbs, R. J., and Suding, K. N.: Management of novel ecosystems: are novel approaches required?, Front. Ecol. Environ., 6, 547-553, doi:10.1890/070046, 2008.

Smith, P., Cotrufo, M. F., Rumpel, C., Paustian, K., Kuikman, P. J., Elliott, J. A., McDowell, R., Griffiths, R. I., Asakawa, S., Bustamante, M., House, J. I., Sobocká, J., Harper, R., Pan, G., West, P. C., Gerber, J. S., Clark, J. M., Adhya, T., Scholes, R. J., and Scholes, M. C.: Biogeochemical cycles and biodiversity as key drivers of ecosystem services provided by soils, SOIL, 1, 665685, doi:10.5194/soil-1-665-2015, 2015.

Taylor, G., Spain, A., Nefiodovas, A., Timms, G., Kuznetsov, V., and Bennet, J.: Determination of the reasons for deterioration of the Rum Jungle waste rock cover, Brisbane, Australian Centre for Mining Environmental Research, 2003.

van Genuchten, M. T.: A Closed-form Equation for Predicting the Hydraulic Conductivity of Unsaturated Soils, Soil Sci. Soc. Am. J., 44, 892-898, doi:10.2136/sssaj1980.03615995004400050002x, 1980.

Venkatraman, K. and Ashwath, N.: Field performance of a phytocap at Lakes Creek landfill, Rockhampton, Australia, Management of Environmental Quality: An International Journal, 21, 237-252, doi:10.1108/14777831011025571, 2010. 
Vogel, T., Cislerova, M., and Hopmans, J. W.: Porous Media With Linearly Variable Hydraulic Properties, Water Resour. Res., 27, 2735-2741, doi:10.1029/91wr01676, 1991.

Wang, D., McSweeney, K., Lowery, B., and Norman, J. M.: Nest structure of ant Lasius neoniger Emery and its implications to soil modification, Geoderma, 66, 259-272, doi:10.1016/00167061(94)00082-L, 1995.
Williams, E.: Ant community response to management practices on rehabilitated mine sites, Doctorate of Philosophy Thesis, The University of Queensland, 2011.

Wilson, G. W., Williams, D. G., and Rykaart, E. M.: Integrity on Cover Systems - An Update, 6th International Conference on Acid Rock Drainage, Cairns, Australia, available at: https://www.ausimm.com.au/publications/epublication.aspx? ID=1031 (last access: 6 January 2016), 2003. 